\title{
How is it that Learning Mathematics in the Early Years Can Become So Difficult? A Post-structuralist Analysis
}

\author{
MARY KLEIN \\ James Cook University, Cairns, Australia
}

\begin{abstract}
New times demand new interpretations of what it means to be numerate in a global world. Policy and curriculum documents uphold notions of capable young learners, actively engaged in investigative learning processes that will carry them on to competent and confident participation in the social and economic world of tomorrow. However, as the author attempts to show in this poststructuralist analysis, active learning processes do not always achieve the envisaged aims; subconsciously, teachers hold on to traditional notions of learners and learning mathematics that, in practice, eclipse their best intentions. Even in the early years of schooling the process of learning mathematics becomes difficult when the new becomes the old, and tired old teaching practices and relationships prevail.
\end{abstract}

It is my impression that young children are quite fascinated by mathematical ideas and have an easy and energetic way of working with them when they come to school (Askew \& William, 1995; Hughes, 1986). Indeed, they are able to solve simple problems and count purposefully with few mistakes (Lambert, 2000). Over time, though, this fascination often fades and these very same students are not backward in asserting that they neither like mathematics, nor the learning of it. As stated in A National Statement on Mathematics for Australian Schools (1990, p. 31) 'there is considerable evidence that children come to school enthusiastic and eager to learn mathematics' and 'leave school with quite negative attitudes'. How is it that an initial desire to use and learn mathematics waxes and wanes and initial interest turns to aversion?

This is not an easy question to answer, though it is an important one especially for children in the early years of schooling where, I suspect, feelings of alienation and disenfranchisement take root. Although policy (Department of Education and Employment, DfEE, 1995; Queensland Studies Authority, 2005) recommend learners' active engagement in environments of investigation and play, little has changed in classrooms (Askew \& William, 1995; Hardy, 2004; Willoughby, 2000) where routinised computation and worksheet or textbook work prevail. A problem that frames my argument in this paper is that the mooted changes do not merely tinker at the periphery of one's established teaching practice, but qualitatively change teaching-learning relationships to emphasise the active and productive role of pupils (even very young pupils) as initiators of learning and creators of knowledge. The new ways-of- being a learner (and teacher) of mathematics are premised on new power relationships and new conceptions of learners and what it means to learn mathematics. A case I attempt to argue in this paper is that learning mathematics becomes so difficult for many students because, oddly enough, their active engagement ends up being little more than pretence and the mathematics itself is stripped of its robustness and structural properties. This happens because teachers' taken-for-granted humanist assumptions about learners, in practice, eclipse their best intentions. 
To advance my argument, I have analaysed a short excerpt from an early years' mathematics lesson (cited in Hardy, 2004, pp. 110-111) focusing on the kind of engagement and subjectivity (identity) available to the learners of mathematics in this one classroom. This passage is of particular interest because in it one is given access to the teacher's constructions of her teaching practices, and her readings of the students' active engagement. From a poststructuralist perspective, where I assume that learners are produced (and establish themselves) as capable or not within the discursive practices of the classroom, I comment on how this teacher's instructional practices (based on humanist assumptions of rational, autonomous, psychological individuals) might be seen to disenfranchise her young pupils.

\section{Reading Practice through a Different Lens}

Mathematics classrooms worldwide operate on humanist understandings of learners. Mathematics education is informed by Piaget's child development through stages, Vygotsky's social interaction as a key force in the development of mind, and Lave's (Lave \& Wenger, 1991) 'situating' learning in socially supportive contexts; each of these is framed by notions of the rational, autonomous learner of mathematics and the principles of developmentally appropriate practice (DAP). As Yelland \& Kilderry (2005) point out, these intersecting notions and teaching principles comprise a metanarrative informing education in the early years, and it is difficult to understand children and learning outside of this discursive frame. However, while the theories above make important epistemological contributions regarding the construction of mathematical ideas, they do not recognise how learners themselves, and what counts as mathematics, are produced in teachinglearning interaction (which often privileges adult control and direction and ignores diversity). That is, these theories are silent on the ontological dimension of how it is that so many young students get 'turned off mathematics and wouldn't do it even if they could (Willoughby, 2000). As suggested by Yelland \& Kilderry (2005), if developmental theories such as Piaget's could be removed from positions of primacy in the field, new ways of engaging with learning in the early childhood years might emerge.

A post-structuralist analysis, concentrating on the constitutive or productive power of instructional (discursive) practices, imagines that learner identities are produced in relationships of power, where learners should be able to recognise themselves as competent and authoritative (in the sense of having authorship of ideas and practices) in performing mathematical tasks and applications. I offer this reading as an alternative to the more common, psychological (humanist) reading of learners and 'why' they find mathematics difficult, or easy. A teacher might ask why Trudy can figure out the mathematics and Tom cannot. Has Tom not been listening? Has he not done the homework? Is he just not good at figuring out? Each question is laden with some sort of implied deficit on Tom's part and leaves the teacher nowhere to go, other than to position Tom as 'not good at figuring out' and in need of help. Although we are not likely to be able to dispense with humanist ways of reading the world, a post-structuralist analysis attempts to make visible how the use of language, as in Tom's case, produces what is taken to be real (Weedon, 1987); in this case, that Tom is just not good at 'figuring out'.

In Table I (adapted from Davies \& Gannon, 2005) humanist and post-structuralist notions of the learner and learning are compared. Humanism takes for granted rational, autonomous learners who arecompetent and capable' as in the Early Years Curriculum Guidelines (Queensland Studies Authority, 2005). On the other hand, post-structuralism posits a contradictory, multiple, multilayered self constituted through a range of discourses throughout life. Under post-structuralist assumptions, human learners are seen to be neither essentially rational nor autonomous, and competent and generative participation in a discourse is conditional on power relationships in the discursive practices of the particular learning environment. 


\begin{tabular}{|c|c|c|}
\hline & HUMANISM & POSTSTRUCTURALISM \\
\hline LEARNER & $\begin{array}{l}\text { Rational, coherent, } \\
\text { autonomous being. } \\
\text { Ability and attitude are } \\
\text { personal attributes }\end{array}$ & $\begin{array}{l}\text { One's identity (subjectivity) is } \\
\text { constituted in discourses such } \\
\text { as mathematics education } \\
\text { through one's own and others' } \\
\text { acts of speaking and writing. } \\
\text { The learner seeks to be } \\
\text { recognisable (by oneself and } \\
\text { others) as a legitimate } \\
\text { participant in the school } \\
\text { mathematics discourse (and } \\
\text { discursive practices). }\end{array}$ \\
\hline LEARNING & $\begin{array}{l}\text { Learning mathematics is } \\
\text { about constructing } \\
\text { knowledge. Learning } \\
\text { choices are based on } \\
\text { rational thought; those } \\
\text { who do not make the } \\
\text { 'correct' choices are } \\
\text { somehow at fault. }\end{array}$ & $\begin{array}{l}\text { Intellectual and self knowledge } \\
\text { (identity) are constituted in the } \\
\text { learning process. Learning is } \\
\text { rhizomorphous, rather than } \\
\text { linear, a process of establishing } \\
\text { oneself as competent, } \\
\text { confident and agentic in a } \\
\text { particular discursive field }\end{array}$ \\
\hline
\end{tabular}

Table I. Humanist and Poststructuralist notions of the individual

A post-structuralist analysis focuses on discourse and discursive and regulatory practices (Davies $\&$ Gannon, 2005). Any setting where discourses are mobilised can be chosen for research; in this instance I have chosen an interaction between a teacher and her young charges in mathematics. The data that I present are examined not as if they described or explained the 'real world' of this classroom, but as constitutive work that is implicated in the production of identities (subjectivities) and the reproduction of the taken-for-granted of teaching mathematics. Mathematics education is a discursive field in which the discourses of mathematics and education come together as discursive practices (group work, marking with ticks and crosses, asking direct questions) that structure learning experiences; the way in which mathematics education is played out in any context affects the extent to which learners can establish and recognise themselves as mathematically competent and confident. In a sense, then, no matter what the instructional practices in school mathematics, they are productive in that they are producing knowing (Lather, 1991) not only about what it means to learn and do mathematics, but also about one's identity as (in)numerate (and, also of interest in this article, as an 'effective' teacher).

\section{Active Learning in Mathematics}

This extract is made up of interview scenes where the teacher comments on her classroom practices (it is taken from Hardy, 2004, 110-111). These are interspersed with classroom scenes where the teacher moves around the room asking short calculation questions of the class. Her questions and instructions are presented to the whole class, whether she is referring to the children as a whole group or as individuals. The children's desks are arranged in blocks of six and each child has two sets of cards, both numbered from 0 to 9 , in front of them. They hold up cards to show their answers to the questions asked:

Comment from Teacher:

A few children don't put their hands up. They try to hide, but that's the idea. There is no hiding place. You encourage them all as long as you give them positive feedback. Even if they get it wrong, they are not scared to give an answer. 
In Classroom Scene

Teacher: Show me a multiple of 5 bigger than $75 \ldots$ Is that a multiple of five though, Michael? It's bigger than 75 but check it's a multiple of five ...

Well done Sarah!

Teacher: Show me three threes..

Three threes? Check again please, Lauren.

Check please, Joe. You are looking at someone else's. Don't just look at someone else's. If you're not sure get your fingers and count in lots of three. Let's do it together (chanting) three, six, nine. You should be showing me nine there.

Comment from Teacher:

Some children don't have instant recall of three threes but I've given them a method to work it out. 'Get your fingers and count in threes.' So as long as they do regular counting in threes and they've got that pattern, they have got a method to do it. When I see the children struggling I take them back to the method or strategy that we've talked through together to help them through that. They are not stood in queues waiting to get a book marked; they are getting instant feedback. They are not scared to get an answer wrong. They're having a go, they are risking things, and you don't gain anything unless you have a few risks and that's what they are doing.

In Classroom Scene:

Teacher: Have a quick check of that one, Misha. You should be showing me twelve.

Comment from Teacher:

It really works. We've seen it work. The children are motivated. The children want to learn. You never have to tell children 'Are you messing around?' They're not. They are trying. They might not be succeeding but they are trying. They really love the pace. Children don't like sitting for 20, 30 minutes on one task especially if they are struggling on it. This doesn't allow that. The children have to find answers. They work together. They help each other but they are pushing forward. The task is changing all the time. As long as you stay focused on target, most lessons you achieve $80 \%$ of children come out learning something that they didn't go in knowing and that's a wonderful experience and encourages you to go on further.

In the sections below, I analyse how the teacher constitutes herself and her students in these interactions, and how together they constitute what it means to teach and learn mathematics. I provide one of many possible readings of the processes of subjectification (identity formation) at work in this classroom.

\section{The Nurturing, Giving Teacher and the Needy Student}

Throughout the scenario above the teacher establishes herself as a nurturing, caring teacher. She speaks nicely to her pupils: 'Check please, Joe,' and 'Check again please, Lauren.' In one instance she speaks of her concern for their physical comfort: 'They are not stood in queues waiting to get a book marked; they are getting instant feedback'. As their teacher, she 'gives' them little gifts, 'patterns' and 'methods' to help them through: 'Some children don't have instant recall of three threes but I've given them a method to work it out. Get your fingers and count in threes. So as long as they do regular counting in threes and they've got that pattern, they have got a method to do it. When I see children struggling I take them back to the method or strategy that we've talked through together to help them through that'.

On the other hand, the students are produced or constituted in her talk and actions as 'needy': they need her help to stop them being scared and to get the correct answers. For example, some children are aberrant in choosing not to 'do school' correctly, they try to hide; however, the teacher makes it all OK through her capacity to nurture them through it: 'A few children don't put their hands up. They try to hide, but that's the idea. There is no hiding place. You encourage them 
all as long as you give them positive feedback. Even if they get it wrong, they are not scared to give an answer.' The teacher and her students together constitute the teaching of mathematics as an act in a play where the teacher directs and checks the students' actions as they strive to carry out her bidding, in what she considers to be a safe and supportive learning environment:

Teacher: Show me a multiple of five bigger than 75 ... Is that a multiple of five, though, Michael? It's bigger than 75 but check it's a multiple of five ...

Teacher: Show me three threes ... Three threes? Check again please, Lauren. Check please, Joe. You are looking at someone else's. Don't just look at someone else's. If you're not sure get your fingers and count in lots of three. Let's do it together (chanting) three, six, nine. You should be showing me nine there.

Teacher: Have a quick check of that one, Misha. You should be showing me twelve.

Together the teacher and her students constitute what it means to teach and learn mathematics. It is an uncomplicated view which is commonly taken for granted in classrooms. Teaching is about constantly testing what children know, in this case, of number concepts in the early years. The children have cards that they hold up to display their knowledge. Instructional practices are about maintaining a fast pace so that the children do not drift off and lose concentration. Teaching is about nurturing and helping; giving small gifts of knowledge and strategies that the children can supposedly use in the future. Learning mathematics, on the other hand, is about actively responding to the teacher's directives; it involves coming up with the correct answer as quickly as possible. Learning mathematics is very dependent on the teacher; the teacher asks the questions and provides the answers if the children cannot arrive at the correct response alone.

The teacher viewing her students in humanist terms gives herself permission to posit only positive outcomes from her teaching interactions in the classroom; after all, as she says, 'It really works.' In this case, the students are spoken of in essentialist terms as if they are all experiencing learning mathematics in exactly the same way: the children are motivated; they want to learn; they are not messing around; they are not always succeeding but they are trying; they love the pace; they work together; they help each other; they are pushing forward; $80 \%$ of them come out learning something they didn't go in knowing. The classroom is painted as a beehive of activity, and out of all this activity the mathematically competent and numerate child is supposedly born. But what of the $20 \%$ who do not learn any mathematics and those who 'try to hide'? Are there some unseen and unintended effects of this teaching style that makes learning mathematics more difficult than anticipated for young learners?

\section{Making Learning Difficult}

It could be argued that learning mathematics becomes difficult for young learners because the learning process is stolen from them. When children come to school they have an already constituted way-of-being a mathematically competent and confident learner (Lambert, 2000) that, I would argue, is effectively taken over by the teacher. Process becomes procedure as, in the indications of teaching above, every action is teacher initiated and directed: it severely limits the field of operation of the students (Foucault, in Dreyfus \& Rabinow, 1982). Students should be able to recognise themselves as legitimate participants of the learning mathematics discourse; they need to be acknowledged and valued as persons who have knowledge and experiences that can be used to enliven and enrich their learning, and ideas and suggestions that can take the production of knowledge forward as a collaborative effort. Students want to be legitimate participants, not sidelined, in the 'game of truth' (Foucault, in Bernauer \& Rasmussen, 1987, p. 1) that is constitutive of their identity as engaged and capable learners of mathematics.

At a practical classroom level, the key issue seems to be that of authority, the state of being an author, of mathematical ideas and practices. For more than twenty years educators have been talking and writing about students actively constructing their own knowledge in mathematics; however, this has been seen solely as an epistemological issue and no account has been taken of how simultaneously the learning environment either supports or suppresses their participation. For example, in the excerpt above, although the teaching is meant to be a two-way process where 
'pupils are expected to play an active part', this is a scripted part 'answering questions, contributing points to discussions, and explaining and demonstrating their methods to the class' (DfEE, 1999, p. 11). Collectively the students take up identity positions as receivers or collectors of others' already created knowledge, not as active and engaged instigators of novel ways of working with mathematical ideas and processes. Mathematics education in the above scenario operates to position the learners as needful of the teacher's help and correction, and makes more engaged and generative participation on their part unthinkable (Britzman, 2003).

It is significant that in the title of this article I ask 'how' rather than 'why' learning mathematics becomes so difficult for many young learners. I am signalling that I am invoking the post-structuralist notion of the constitution of identity (subjectivity) with/in discursive (instructional) practices in the mathematics classroom. It is not that the mathematics is difficult, but that the learning becomes so because of teachers' humanist assumptions about learners and the unproblematic application of factual knowledge. A worrying issue is that young children are not able to actively participate in discursive practices upholding mathematics as a socially informed 'method of reasoning, a way of figuring out a certain kind of system and structure in the world' (Australian Council of Deans of Education, 2001, 89), rather than as the collection of disparate 'methods' and bits of knowledge. Ultimately, the discursive practices and relationships of the classroom render this necessarily learner initiated 'figuring out' of system and structure impossible.

\section{Conclusion}

As Yelland \& Kilderry (2005) suggest, old frameworks informing early years' education should be interrogated for their effects in/on practice. This post-structuralist analysis is ultimately about relationships of power in teaching and learning interactions in mathematics. I suggest that educators and researchers may not fully appreciate the alienating effects of instructional practices that deny learners a genuine voice and the opportunity to make sense in personally meaningful ways. Although the rhetoric surrounding mathematics education includes notions of sense making and active engagement, in practice many learners find themselves served up an emaciated form of mathematics in learning environments that merely pretend to entice. As Keith Devlin (2000, 254) stated: 'The key to be able to do mathematics is wanting to.' Much more research needs to be done into how it is that so many young learners ... just don't want to.

\section{Correspondence}

Mary Klein, School of Education, James Cook University, PO Box 6811, Cairns, Queensland 4870, Australia (mary.klein@jcu.edu.au).

\section{References}

Askew, M. \& William, D. (1995) Recent Research in Mathematics Education. London: HMSO.

Australian Council of Deans of Education (2001) New Learning: a charter for Australian education. http:/ / www.acde.org.

Australian Education Council (1990) A National Statement on Mathematics for Australian Schools. Carlton, Victoria: Curriculum Council.

Bernauer, J. \& Rasmussen, D. (1987) The Final Foucault. Cambridge, MA: MIT Press.

Britzman, D. (2003) Practice Makes Practice: a critical study of learning to teach. Albany, NY: State University of New York Press.

Davies, B. \& Gannon, S. (2005) Feminism/Poststructuralism, in B. Somekh \& C. Lewin (Eds) Research Methods in the Social Sciences (pp. 318-325). London: Sage Publications.

Department for Education (1995) Mathematics in the National Curriculum. London: HMSO.

Department for Education and Employment (DfEE) (1999) National Numeracy Strategy: framework for teaching mathematics from reception to year 6. Sudbury: DfEE Publications.

Devlin, K. (2000) The Maths Gene: why everyone has it but most people don't use it. London: Phoenix. 
Dreyfus, H. \& Rabinow, P. (1982) Michel Foucault: beyond structuralism and hermeneutics. New York: Harvester Wheatsheaf.

Hardy, T. (2004) There's no hiding place, in M. Walshaw (Ed.) Mathematics Education Within the Postmodern (pp. 103-119). Greenwich, CT: Information Age Publishing.

Hughes, M. (1986) Children and Number. Oxford: Blackwell.

Lambert, E.B. (2000) Problem-solving in the first years of school, Australian Journal of Early Childhood, 25(3), 32-38.

Lather, P. (1991) Getting Smart. London: Routledge.

Lave, J. \& Wenger, E. (1991) Situated Learning: legitimate peripheral participation. Cambridge: Cambridge University Press.

Queensland Studies Authority (QSA) (2005) Early Years Curriculum Guidelines. http:/ / www.qsa.qld.edu.au/ early/ curriculum_guidelines (accessed 11 June 2006).

Weedon, C. (1987) Feminist Practice and Poststructuralist Theory. Cambridge, MA: Blackwell.

Willoughby, S. (2000) Perspectives on Mathematics Education, in M.J. Burke \& F. Curcio (Eds) Learning Mathematics for a New Century (1-15). Reston, VA: National Council of Teachers of Mathematics.

Yelland, N. \& Kilderry, A. (2005) Against the Tide: new ways in early childhood education, in N. Yelland (Ed.) Critical Issues in Early Childhood Education (pp. 1-11). Maidenhead: Open University Press. 